\title{
The Spider Steatoda triangulosa Walckenaer as a Biocontrol Agent Against Tetranychus urticae Koch in Green Houses
}

\author{
Aml H. M. Romeih*; M. H. El- Erkousousy ${ }^{* *}$ and A. K. Aiad ${ }^{* *}$ \\ ${ }^{*}$ Agric. Zool. Dept., Fac. Agric. Cairo University, Giza, Egypt \\ ** Plant Protect. Res. Inst., Agri. Res. Center, Dokki, Giza, Egypt
}

\begin{abstract}
Two levels of Steatoda triangulosa (25 and 50 individuals/ replicate) were released (one time); on $29^{\text {th }}$ September 2005 at rate 50 individuals and on $20^{\text {th }}$ April 2006 at a rate 25 individuals. For the first level of release, the pre-count in the releasing area with T. urticae was 12.1 individuals / leaf; while it was 12.9 individuals / leaf in (check). The number of T. urticae in the $1^{\text {st }}$ release/ plot decreased gradually from 12.1 on $29^{\text {th }}$ September to $8.03,5.9,5.03,6.36$ and 5.8 individuals / leaf on 6, 13, 20, 27 October and 3 November, respectively. T. urticae populations per check plot changed from 12.9 individuals / leaf on $29^{\text {th }}$ September to 15.0, 22.9, 25.1, 31.6 and 54.7 individuals / leaf in the same dates, respectively. Percent reduction of $T$. urticae in $1^{\text {st }}$ release plot increased gradually to reach $20,65,62,62$ and $80 \%$ on the previously mentioned days of October and November, respectively. For the second level of release, the pre-count in the releasing area with T. urticae was 7.7 individuals / leaf; while it was 6.7 individuals / leaf in (check). The number of $T$. urticae in the $1^{\text {st }}$ release plot decreased gradually from 7.7 on $20^{\text {th }}$ April to 6.4, 3.9, 3.4, 1.4 and 0.6 individuals / leaf on 30 May, the $10^{\text {th }}, 20^{\text {th }}, 30^{\text {th }}$ June and $10^{\text {th }} \mathrm{July}$, respectively. Compared to check plot, T. urticae populations changed from 6.7 individuals / leaf on $20^{\text {th }}$ April to 11.3,11.2, 18.9, 25.7 and 30.2 individuals / leaf on the same dates, respectively. In addition, the percent reduction of $T$. urticae increased gradually to reach 51.0, 69.0, 85.0, 95.0 and 81.0\%, respectively.
\end{abstract}

Key Words: Biocontrol, Steatoda triangulosa, Tetranychus urticae.

\section{INTRODUCTION}

Spiders are among the most abundant predators of insects of terrestrial ecosystems (Tischler 1965). Under favorable conditions they can reach maximal densities up to 1000 individuals/m2 approximately (Pearse 1946). Therefore it has been supposed that they may play an important role as stabilizing agents and/or regulators of insect populations in agroecosystems and forest ecosystems. In spite of the large number of existing studies, the significance of the spiders as natural control agents in agroecosystems is still largely unknown. This could be attributed to that most studies were limited either to the investigation of the species composition and the seasonal occurrence in the field or to food consumption tests, and prey preference trials in the laboratory. However, the results of investigations on the nutrition of spiders in the laboratory can not readily be extrapolated to field conditions, because spiders may behave differently in the laboratory than in the field.

\section{MATERIALS AND METHODS}

The spiders were collected from the field; put in a small plastic box then transferred to the laboratory for classification. Steatoda triangulosa Walckenaer was separated and sexed to males and females. Females that carried egg sacs were preferred while others, in unsatisfactory condition were excluded. The previous procedures were applied many times in different fields and from varied crops. All S. triangulosa individuals were deposited randomly into rearing box unit (R.B.U.) . The ratio between male and female was $1: 1$ and the number of spiders in the beginning of the experiment were 50 individuals .

\section{a. Rearing box unit (R.B.U.)}

The frames of the (R.B.U.) and its four legs were made of aluminum and its dimensions were $60 \mathrm{~cm}$ long, $25 \mathrm{~cm}$ width and $30 \mathrm{~cm}$ height. The two bigger sides and the bottom were made of glass while the two small ones were made of tiny perforated screen. The R.B.U. had a lid that was also made of tiny perforated screen for supplying the spiders with prey .The four legs of R.B.U. were put in plates filled with water to prevent the ants and placed on table which was cleaned daily. The spiders were supplied daily with surplus of different preys. After increasing the population of spiders inside the R.B.U., some were transported to another cage with the same sex ratio of male to female and kept till the spiders reached nearly to the same number of the first R.B.U. and so on.

\section{b. Releases}

Releasing study was conducted on bean plants, Phaseolus vulgaris (L.) under greenhouse conditions in Giza governorate during winter (2005). The area $\left(12 \times 1.5 \mathrm{~m}^{2}\right)$ was divided to two similar treatments $\left(6 \times 1.5 \mathrm{~m}^{2}\right)$.each divided into three replicates $\left(2 \times 1.5 \mathrm{~m}^{2}\right)$ separated from each other by theran and polyethylene from all sides. All replicates were infested with Tetranychus urticae mites. Releasing 
the spiders started on $29^{\text {th }}$ September 2005 at rate of 50 spiders /replicate. The spiders individuals were released through small plastic boxes each contained one individual of spider. Samples of ten leaves /replicate were taken from treatment and control, just before releasing and counted as a pre-count. The post counts were taken after $7,14,21,28$ and 35 days.

Another level of releasing occurred on $20^{\text {th }}$ May, 2006 at rate the 25 spiders /replicate but the post counts were taken after 10,20,30and 40 days under the same previous conditions.

\section{Statistical analysis:}

The biological studies were calculated according to Stander Division (SAS, 1998). The statistical equation of Henderson and Tilton (1955) was applied to calculate the percentage of reduction of T. urticae. In addition, the moving stages of spiders were recorded.

\section{RESULTS AND DISCUSSION}

\section{a. First level (50 Steatoda triangulosa individuals / replicate)}

In the first level of release, the pre-count in the releasing area with $T$. urticae was 12.1 individuals / leaf; while it was 12.9 individuals / leaf in check. The results in table $1 \&$ fig. 1 indicated that the average number of $T$. urticae in the $1^{\text {st }}$ release plot decreased gradually from 12.1 individuals on $29^{\text {th }}$ September to $8.0,5.9,5.0,6.4$ and 5.8 individuals/leaf on $6,13,20,27$ October and 3 November, respectively. Comparing to check plot. T. urticae populations increased from 12.9 individuals /leaf on $29^{\text {th }}$ September to $15.0,22.9,25.1,31.6$ and 54.7 individuals/leaf in the same dates, respectively.

In addition, the results showed that the percent reduction of $T$. urticae in $1^{\text {st }}$ release plot increased gradually to reach $20,65,62,62$ and $80 \%$ on 6,13 , 20, 27 October and 3 November, respectively.

\section{b. Second level (25 Steatoda triangulosa individuals/replicate)}

In the second level of release, the pre-count in the releasing area with $T$. urticae was 7.7 individuals /leaf; while it was 6.7 individuals/leaf in the check. The results in table $2 \&$ fig. 2 indicated that the number of $T$. urticae decreased gradually from 7.7 on $20^{\text {th }}$ of April to 6.4, 3.9, 3.4, 1.4 and 0.6 individuals / leaf on 30 May, 10, 20, 30 June and 10 July, respectively. Compared to the check plot .T. urticae populations increased from 6.7 individuals / leaf on $20^{\text {th }}$ of April to 11.3, 11.2, 18.9, 25.7 and 30.2 individuals / leaf on the aforementioned dates, respectively.

In addition, the results showed that, the percent reduction of $T$. urticae increased gradually to reach $51.0,69.0,85.0,95.0$ and $81.0 \%$, on the successive dates, respectively.

Results showed that reduction percentage of T. urticae was higher in the releasing of level of 25 spider individuals/replicate in comparing with level 50 individuals of spider / replicate .This might be due to the cannibalism within the high number of spider.

Norgaad (1951) demonstrated that two lycosid species in same habitat were abundant and fed upon similar small animals and also preyed each other. Greenstone (1978) found that no correlation between the population density or individual size of the wolf spider Paradosa ramulosa and prey availability at 24 brackish around which the spiders aggregate.

Table (1): \% Reduction of Tetranychus urticae in population in the $1^{\text {st }}$ plot release at level (50 individuals/replicate) of spider Steatoda triangulosa on bean plants during 2005 .

\begin{tabular}{cccc}
\hline Date & $\begin{array}{c}\text { Check } \\
\text { plot }\end{array}$ & $\begin{array}{c}\text { Release } \\
\text { plot }\end{array}$ & $\begin{array}{c}\text { Reduction\% of } \\
\text { Tetranychus } \\
\text { urticae }\end{array}$ \\
\hline 29Sept. & 12.1 & 12.9 & \\
\hline 6Oct & 15 & 8.03 & 20 \\
\hline 13Oct. & 22.9 & 5.9 & 65 \\
\hline 20Oct. & 25.6 & 5.03 & 62 \\
\hline 27Oct & 31.6 & 6.36 & 62 \\
\hline 3 Nov. & 54.7 & 5.8 & 80 \\
\hline
\end{tabular}

Table (2): \% Reduction of Tetranychus urticae in the $1^{\text {st }}$ plot release at level of 25 Steatoda triangulosa individuals / replicate) on bean plants during 2006.

\begin{tabular}{cccc}
\hline Date & $\begin{array}{c}\text { Check } \\
\text { plot }\end{array}$ & $\begin{array}{c}\text { Release } \\
\text { plot }\end{array}$ & $\begin{array}{c}\text { \% Reduction of } \\
\text { Tetranychus urticae }\end{array}$ \\
\hline 20 April & 6.7 & 7.7 & \\
\hline May 30 & 11.3 & 6.4 & 51.0 \\
\hline Jun.10 & 11.2 & 3.9 & 69.0 \\
\hline Jun.20 & 18.9 & 3.4 & 85.0 \\
\hline Jun 30 & 25.7 & 1.4 & 95.0 \\
\hline July 10 & 30.2 & 0.6 & 81.0 \\
\hline
\end{tabular}






Fig.(1): Population dynamic of Tetranychus urticae in the $1^{\text {st }}$ plot release at level 50 spider, Steatoda triangulosa individuals / replicate and the corresponding \%reduction of the mite density on bean plants during 2005.

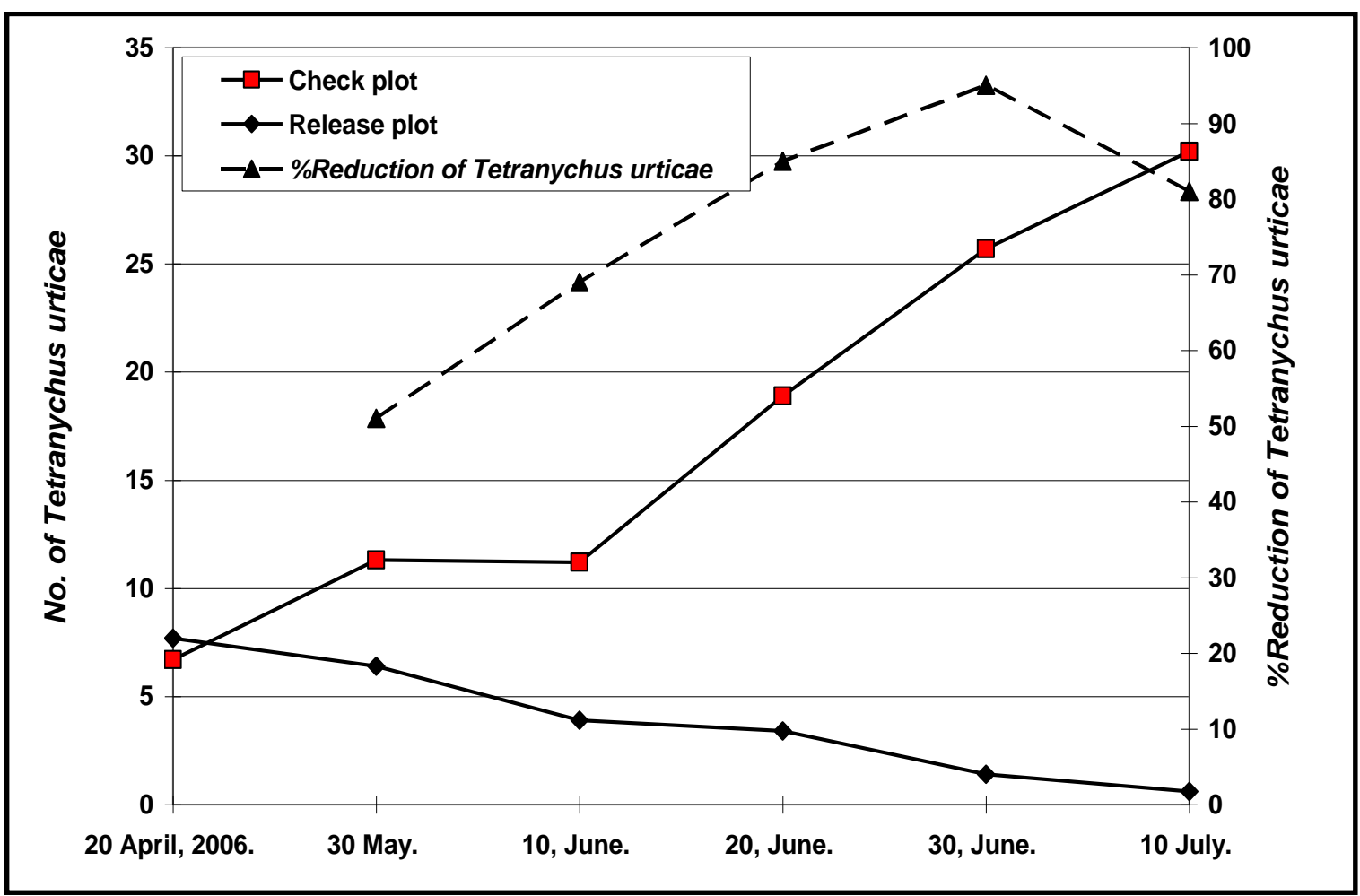

Fig. (2): Population dynamic of Tetranychus urticae in the $1^{\text {st }}$ plot release at level $(25$ spider, Steatoda triangulosa / replicate) and the corresponding \%reduction of the mite density on bean plants during 2006. 
Furthermore, Kajak (1965) found that no correlation ocurred between the abundant of Diptera in sweep-net samples and the densities of two species of Araneus in meadow. In addition, she found that no correlation occurred between spider density and the rate of prey capture per spider. Weickmann and Burda (1995) reported that of 20 species of the family Theridiidae only 5 species were particularly suitable as predators in vineyards and greenhouses as they were easy to breed. Steatoda paykulliana was one of those species according to Weickmann and Burda.

Further research should be undertaken to determine the right number of every spider species needed to control the plant feeder pests.

\section{REFERENCES}

Greenstone, M. H. 1978. The numerical response to prey availability of Paradosa ramulosa (Mc Cook) (Araneae: Lycosidae) and its relationship to the role in the balance of nature. Symposia of the
Zoological Society of London, 42:183-193.

Hagstrum, D. W. 1970. Ecological energetics of the spider Tarentula kochi (Araneae: Lycosidae). Ann. Ent. Soc. Am., 63:1297-1304.

Kajak, A.1965. An Analysis of food relations between the spiders-Araneus cornutus Clerk and Araneus quadratus Clerk and their prey in meadows. Ekologia polska-Seria A, 13: 717762 .

Norgaad, E. 1951. On the ecology of two lycosid spiders (Pirata piraticus and Lycosa pullata) from a Danish Sphagnum bog.Oikos, 3: 1-21.

Pearse, A. 1946. Observations on the microfauna of the Duke forest. Ecol. Monographs, 16: 127-150.

Tischler, V. 1958. Svnökologische Untersuchungen an der Fauna der Felder und Feldgehölze Ein deitrag zur Ökologie äer Kulturlandschaft). Z. Morph. Ökol. Tiere, 47: 54-114.

Weickmann, D. and Burda, R. 1995. Spiders of the family Theridiidae in biological control. Mededelingen Faculteit Landbouwkundige en Toegepaste Biologische Wetenschappen, Universiteit Gent., 60(3a): 799-801. 